\title{
Kronika getta tódzkiego /Litzmannstadt Getto, oprac. Julian Baranowski, Krystyna Radziszewska, Adam Sitarek, Michał Trębacz, Jacek Walicki, Ewa Wiatr, Piotr Zawilski, Archiwum Państwowe w Lodzi, Wydawnictwo Uniwersytetu Lódzkiego, Łódź 2009, t. 1-5
}

W sierpniu 2009 r., w 65. rocznicę likwidacji getta łódzkiego ukazało się pełne, pięciotomowe wydanie Kroniki, monumentalnego zbioru dokumentów powstałych i przechowywanych w czasie wojny w Wydziale Archiwum Przełożonego Starszeństwa Żydów w getcie łódzkim. Próbę edycji tych materiałów podjęli jeszcze w latach sześćdziesiątych ubiegłego wieku Danuta Dąbrowska i Lucjan Dobroszycki. Pierwszy przygotowany przez nich tom Kroniki ukazał się w 1965 r., drugi w 1967. Kolejne dwa, gotowe do druku tomy zniszczono w wyniku antysemickiej nagonki w $1968 \mathrm{r}$. Danuta Dąbrowska i Lucjan Dobroszycki wyjechali z kraju. Szanse na kontynuację ich pracy pojawiły się dopiero na początku XXI wieku. Jak pisze Jacek Walicki, „[i]dea naukowej i pełnej edycji Kroniki getta łódzkiego powstała w Uniwersytecie Justusa Liebiga w Giessen oraz w Arbeitsstelle für Holocaustliteratur, kierowanym wówczas przez prof. Erwina Leibfrieda w 2000 r. Wtedy też doszło do nawiązania współpracy z Uniwersytetem Łódzkim i Archiwum Państwowym w Łodzi, gdyż ten wielki projekt wymagał współpracy przedstawicieli kilku dyscyplin naukowych - historyków, filologów i archiwistów z Polski i Niemiec"1. Niemieckie wydanie Kroniki ukazało się w 2007 r. Dwa lata później pięć tomów łódzkich dokumentów otrzymał do rąk polski czytelnik. Ich wydawcy podkreślają, że polska i niemiecka edycja, choć obejmują ten sam podstawowy tekst Kroniki, mają odrębny charakter, różnią się zarówno językiem (teksty obcojęzyczne tłumaczone były odpowiednio na polski i niemiecki), jak i całą obudową edytorską. Członkowie polskiego zespołu redakcyjnego - spośród których należy wymienić najbardziej oddanych sprawie: Ewę Wiatr, Adama Sitarka, Michała Trębacza i Jacka Walickiego - wykonali imponującą pracę. Podstawowy archiwalny materiał Kroniki ujęty w czterech woluminach został przez nich dokładnie przejrzany, porównany i opatrzony drobiazgowymi przypisami. W piątym tomie edytorzy zawarli mało znane materiały źródłowe, powstałe również w Wydziale Archiwum, wśród nich fragmenty tekstu Historia Getta, zapisy Oskara Singera, Oskara Rosenfelda, Bernarda Heiliga i Alicji de Buton. W tym samym tomie znalazły się dwa porządkujące i wyczerpujące opracowania: Krystyna Radziszewska przedstawiła sylwetki kronikarzy oraz okoliczności powstania Kroniki, a Jacek Walicki poświęcił artykuł powojennym losom tekstu i ludziom, którzy nad nim pracowali. W tomie piątym umieszczono także niezwykle pomocny leksykon postaci i pojęć związanych z gettem, plany żydowskiej dzielnicy pokazujące

\footnotetext{
${ }^{1}$ Wstęp [w:] Kronika getta łódzkiego /Litzmannstadt Getto, s. VII.
} 
zmiany jej granic oraz wykazy nazw ulic. Redaktorzy Kroniki zapowiadają, że ta edycja jest wstępem do dalszych szeroko zakrojonych interdyscyplinarnych badań nad dziejami łódzkiego getta. Następnym ich przedsięwzięciem ma być podanie do druku Encyklopedii Getta, kolejnego fascynującego dokumentu z Wydziału Archiwum. Jestem przekonana, że wykonają swoje zadanie $z$ taką samą pieczołowitością, z jaką przygotowali Kronikę.

Monika Polit 